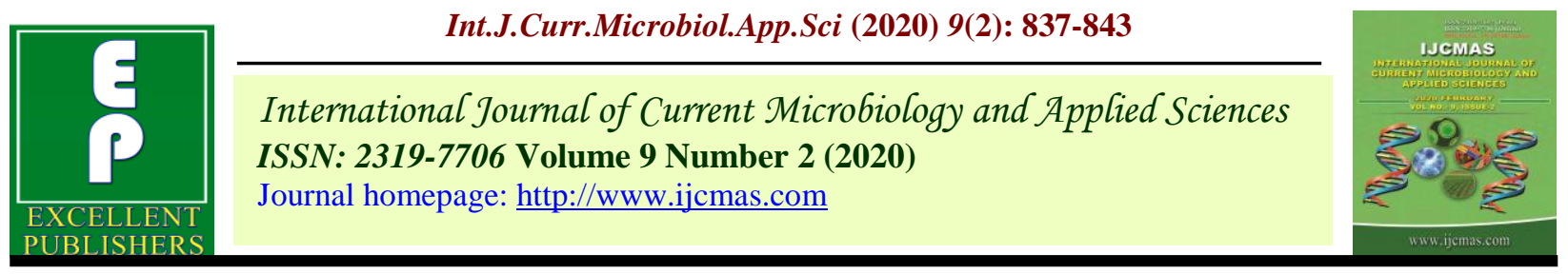

Original Research Article

https://doi.org/10.20546/ijcmas.2020.902.101

\title{
Effect of Supplementation of Organic Acids on Biochemical Status and Gut Health of Japanese Quail (Coturnix coturnix japonica)
}

\author{
A. P. Bansod*, S. M. Wankhede, Sajid Ali, Prajakta S. Kuralkar, \\ G. M. Jadhao and A. D. Jadhao \\ Department of Animal Nutrition, Post Graduate Institute of Veterinary and Animal Sciences, \\ Akola (MS), India \\ Nagpur Veterinary College, Nagpur, India \\ *Corresponding author
}

\author{
A B S T R A C T
}

\begin{tabular}{|l|}
\hline Ke y w or d s \\
Organic acids, \\
Quail, Gut health, \\
Blood Biochemical \\
\hline Article Info \\
\hline $\begin{array}{l}\text { Accepted: } \\
\text { 08 January } 2020 \\
\text { Available Online: } \\
\text { 10 February } 2020\end{array}$ \\
\hline \hline
\end{tabular}

The present research work was conducted to study the performance of Japanese quail (Coturnix coturnix japonica). A total number of 300 birds were reared for a period of thirty five days with dietary treatments; T0 - control diet as per ICAR (2013), T1 - T0+ $0.25 \%$ Acetic acid, T2 - T0 $+0.25 \%$ Butyric acid, T3 - T0+ 0.25\% Propionic acid and T4 $\mathrm{T} 0+0.25 \%$ Acetic acid $+0.25 \%$ Butyric acid $+0.25 \%$ Propionic acid. Each treatment consist of sixty birds with four replicates containing fifteen birds per replicate. Two birds from each replicate of average body weight were selected and slaughtered and blood samples at the end of 35 days were collected for estimation of blood biochemical parameters and for gut health measurement. Blood biochemical parameters viz., total protein, albumin, globulin and cholesterol were found to be significant and triglyceride found non-significant. However there was decreased level of cholesterol in all treatment groups than control. In case of Gut health, ileal $\mathrm{pH}$, intestinal weight, gut thickness, E. Coli and Salmonella count found to be significant.

\section{Introduction}

Globally, production of the primary poultry products (meat and eggs) has been rising rapidly. India is ranking third in egg production and fourth in meat production which indicates the need for increasing production to combat the problem of malnutrition (Poultry sector in India 2017). The growth is 6-8\% in layers and $10-12 \%$ in broilers per annum against the growth of agriculture as a whole. Poultry birds are domesticated avian species that can be reared for eggs and meat. The term "poultry" covers a wide range of birds, from indigenous and commercial breeds of chickens to Muscovy duck, Chickens, ducks, guinea fowl, geese and turkeys can be found in all types of poultry systems, both large and small. But pheasants, quail and ostriches are almost exclusively found in large-scale systems (FAO, 2019). Introduction of quail is one of the critical milestones to fulfill the nutritional requirement by means of eggs and meat along 
with the broilers and the layers. Due to an increasing demand of meat and eggs, use of antibiotics in poultry as a growth promoter is still a common practice in developing countries (Aziz-Mousavi et al., 2012; Shamlo et al., 2014). The ban on the use of antibiotics as growth promoters in EU since 2006 permitted the finding of alternative to antibiotics in farm animal nutrition (Attia et al., 2006; 2012). The poultry sector is continuously in look for new feed additives in order to improve the feed efficiency and health of poultry birds. One such substitute was the use of organic acids as a feed additive in the animal production. Organic acids stimulate the epithelial growth of the intestinal wall (Langhout and Sus, 2005). Dietary organic acids and their salts are able to inhibit the growth of detrimental microbes in the feed and subsequently maintains the level of beneficial bacteria in the gastrointestinal tract. In addition, they not only decrease the $\mathrm{pH}$ of the gastro-intestinal tract but also increases the solubility, digestion and absorption of the nutrients (Vogt et al., 1981; Patten and Waldroup, 1988 and Skinner et al., 1991). These studies would be related to the source, the amount of organic acids used, location, environmental condition and the composition of the diets (Gama et al., 2000). Organic acids are either simple monocarboxylic acids (formic, acetic, propionic and butyric acid) or carboxylic acids with hydroxyl group (lactic, malic, tartaric and citric acid). In undissociated form, they penetrate the semi-permeable membrane of bacterial cell wall, enters the cytoplasm and decrease the internal $\mathrm{pH}$ affecting the enzyme system (e.g. decarboxylases and catalases) thus, inhibiting glycolysis, preventing active transport and interfering with signal transduction. Hence, the supplementation of organic acids in feed instead of sub-therapeutic dosage of antibiotics is being seriously considered, particularly in the context of reservations in using antibiotic as a feed additive Considering the wide scope for the research of combination of single or blends of organic acids give optimum synergistic effect on blood biochemical performance and gut health of Japanese quail, the present study is planned.

\section{Materials and Methods}

An experimental study was conducted to study the effect of organic acids on blood biochemical and gut health of Japanese quail. A total 300 day old chicks were reared for five weeks with dietary treatments, $\mathrm{T}_{0}$ (Standard broiler quail diet as per ICAR, (2013), $\mathrm{T}_{1}\left(\mathrm{~T}_{0}+0.2 \%\right.$ Acetic acid), $\mathrm{T}_{2}\left(\mathrm{~T}_{0}+\right.$ $0.2 \%$ Butyric acid $), \mathrm{T}_{3}\left(\mathrm{~T}_{0}+0.2 \%\right.$ Propionic acid), $\mathrm{T}_{4}\left(\mathrm{~T}_{0}+0.2 \%\right.$ Acetic acid $+0.2 \%$ Butyric acid $+0.2 \%$ ) as shown in table 1 . Each treatment group consisted of sixty birds with four replicates containing fifteen birds in each replication. The birds were reared on deep litter system and proper managemental practices were followed during the entire experimental period. Individual body weight of each bird was recorded at weekly interval and bodyweight gain was calculated as mean of each replicate. The birds from the experimental trial were assessed for the Biochemical parameters and gut health at 35 days of age. Blood samples from eight birds of each treatment (two from each replicate with average body weight) were collected toward the finish of test. The blood samples were collected via jugular vein from each bird and serum was isolated by centrifugation at 3000 RPM for 10 minutes and kept at $-20{ }^{0} \mathrm{C}$ till further investigation. Biochemical parameters included estimation of Total protein, Albumin, Triglyceride and Serum cholesterol utilizing biochemical kits produced by AGD Biomedicals PVT.LTD with the assistance of AGD Biochemistry Auto-analyzer whereas serum Globulin was determined by subtracting Albumin from total 
protein and represented in table 2 . Gut health include intestinal weight, ileum $\mathrm{pH}$, intestinal length, intestinal thickness and total microbial count. For Gut health parameter, the carcass of birds was subsequently opened and the entire gastrointestinal tract was removed aseptically and depicted in table 2 .

The collected data during the study was analyzed statistically as per Snedecor and Cochran (1994) by utilizing Statistical Package for the Social Sciences (SPSS) Version 17.0.

\section{Results and Discussion}

The values of serum total protein $(\mathrm{mg} / \mathrm{dl})$ were $\mathrm{T}_{0^{-}} 2.9 \pm 0.007, \mathrm{~T}_{1}-3.48 \pm 0.021, \mathrm{~T}_{2^{-}}$ $3.69 \pm 0.016, \mathrm{~T}_{3}-3.54 \pm 0.052$ and $\mathrm{T}_{4}-3.74 \pm$ 0.008 with mean $3.47 \pm .049$. Among all the treatment group $\mathrm{T}_{4}$ fed with mixture of organic acids significantly with highest value and among all the treatments however lowest serum total protein value was observed in control group. The values of serum albumin $(\mathrm{mg} / \mathrm{dl})$ for treatment group $\mathrm{T}_{0}$ to $\mathrm{T}_{4}$ with mean were $1.32 \pm 0.011,1.54 \pm 0.014,1.6 \pm$ $0.007,1.65 \pm 0.005,1.65 \pm 0.004$ and $1.56 \pm$ 0.021 respectively. The data pertaining values of serum albumin subjected to analysis of variance found to be significant. The highest value for serum albumin was observed in $T_{3}$ group. Whereas lowest value was observed in treatment group $\mathrm{T}_{0}$ fed normal diet as per ICAR, 2013. The data pertaining values of serum globulin $(\mathrm{mg} / \mathrm{dl})$ subjected to analysis of variance found to be significant. The values for treatment group $\mathrm{T}_{0}$ to $\mathrm{T}_{4}$ with mean $(\mathrm{mg} / \mathrm{dl})$ were $1.59 \pm 0.013,1.94 \pm 0.033,2.03$ $\pm 0.016,1.89 \pm 0.06,2.09 \pm 0.029$ and $1.91 \pm$ .032. It was observed that group $\mathrm{T}_{4}$ fed with blends of acidifier showed numerically highest value among all the treatment group whereas control group showed numerically lowest value. The values for treatment groups of serum cholesterol $(\mathrm{mg} / \mathrm{dl})$ were $\mathrm{T}_{0}-232.87$ $\pm 4.48, \mathrm{~T}_{1}-234.25 \pm 1.96, \mathrm{~T}_{2}-195.87 \pm 0.71$, $\mathrm{T}_{3}-222 \pm 2.02$ and $\mathrm{T}_{4}-213.1 \pm 2.06$ with mean $219.62 \pm 2.51$. Significant differences were found among the treatments. Highest numerical value of serum cholesterol was observed in $\mathrm{T}_{1}$ group $(234.25 \mathrm{mg} / \mathrm{dl})$ whereas lowest value of serum cholesterol was in group $\mathrm{T}_{2}(195.87 \mathrm{mg} / \mathrm{dl})$.

The data pertaining values of Triglyceride $(\mathrm{mg} / \mathrm{dl})$, subjected to analysis of variance found to be non-significant. The values of triglyceride for different treatment groups were $\mathrm{T}_{0}-164.26 \pm 1.08, \mathrm{~T}_{1}-162.45 \pm 1.82, \mathrm{~T}_{2}-$ $162.67 \pm 1.94, \mathrm{~T}_{3}-163.80 \pm 0.78$ and $\mathrm{T}_{4}-$ $161.29 \pm 1.30$ with mean $162.90 \pm 0.63$. Group $\mathrm{T}_{4}$ significantly lower triglyceride as compared to control.

The results obtained in the present study are with respect to total protein and Albumin in accordance with Elnesr et al., (2018) who reported linear increase in serum total protein values when Japanese quails were supplemented with sodium butyrate. Nonsignificant differences for serum total protein were recorded by Naveenkumar et al., (2018) when broilers were fed with diet containing organic acids. Similar results were reported by Abdel-Mageed (2012) in Japanese quails (Coturnix coturnix japonica) when supplemented diet with butyric acid glycerides as a growth promoter. Seifi et al., (2015) observed non-significant differences for serum globulin values of broiler chickens when supplemented with acetic acid. Fouladi et al., (2017) reported significant decrease in serum cholesterol values of Japanese quails when supplemented diet with organic acids. Brzoska et al., (2013) reported non-significant differences for values of serum cholesterol concentration of broilers reared on different dietary treatments when supplemented with organic acids. 
Table.1 Percent ingredient composition of starter diet (Starter phase and Finisher Phase)

\begin{tabular}{|l|l|l|l|l|l|l|l|l|l|l|}
\hline Ingredient (\%) & \multicolumn{9}{|l}{ Starter } & \multicolumn{3}{l|}{ Finisher } \\
\hline & $\mathbf{T}_{\mathbf{0}}$ & $\mathbf{T}_{\mathbf{0}}$ & $\mathbf{T}_{\mathbf{1}}$ & $\mathbf{T}_{\mathbf{2}}$ & $\mathbf{T}_{\mathbf{3}}$ & $\mathbf{T}_{\mathbf{4}}$ & $\mathbf{T}_{\mathbf{1}}$ & $\mathbf{T}_{\mathbf{2}}$ & $\mathbf{T}_{\mathbf{3}}$ & $\mathbf{T}_{\mathbf{4}}$ \\
\hline Maize & 42 & 50.4 & 50.4 & 50.4 & 50.4 & 50.4 & 42 & 42 & 42 & 42 \\
\hline Soybean (DOC) & 48.07 & 38.8 & 38.8 & 38.8 & 38.8 & 38.8 & 48.07 & 48.07 & 48.07 & 48.07 \\
\hline Palm oil & 4 & 4 & 4 & 4 & 4 & 4 & 4 & 4 & 4 & 4 \\
\hline L-Lysine & 0.12 & 0.13 & 0.13 & 0.13 & 0.13 & 0.13 & 0.12 & 0.12 & 0.12 & 0.12 \\
\hline DL-Methionine & 0.14 & 0.25 & 0.25 & 0.25 & 0.25 & 0.25 & 0.14 & 0.14 & 0.14 & 0.14 \\
\hline Arginine & 1.20 & 1.42 & 1.42 & 1.42 & 1.42 & 1.42 & 1.20 & 1.20 & 1.20 & 1.20 \\
\hline Threonine & 1.00 & 0.70 & 0.70 & 0.70 & 0.70 & 0.70 & 1.00 & 1.00 & 1.00 & 1.00 \\
\hline Limestone powder & 1 & 1.12 & 1.12 & 1.12 & 1.12 & 1.12 & 1 & 1 & 1 & 1 \\
\hline Dicalcium & 1 & 1.65 & 1.35 & 1.35 & 1.35 & 1.35 & 1.65 & 1.65 & 1.65 & 1.65 \\
\hline Phosphate & 1.65 & & & & & & & & & \\
\hline Trace-mineral mix & 0.10 & 0.10 & 0.10 & 0.10 & 0.10 & 0.10 & 0.10 & 0.10 & 0.10 & 0.10 \\
\hline Vitamin mixture & 0.05 & 0.1 & 0.1 & 0.1 & 0.1 & 0.1 & 0.05 & 0.05 & 0.05 & 0.05 \\
\hline Salt & 0.3 & 0.4 & 0.4 & 0.4 & 0.4 & 0.4 & 0.3 & 0.3 & 0.3 & 0.3 \\
\hline Choline chloride & 0.12 & 0.13 & 0.13 & 0.13 & 0.13 & 0.13 & 0.12 & 0.12 & 0.12 & 0.12 \\
\hline Coccidiostat* & 0.05 & 0.45 & 0.45 & 0.45 & 0.45 & 0.45 & 0.05 & 0.05 & 0.05 & 0.05 \\
\hline Toxin binder* & 0.10 & 0.10 & 0.10 & 0.10 & 0.10 & 0.10 & 0.10 & 0.10 & 0.10 & 0.10 \\
\hline Acetic acid & - & - & 0.2 & - & - & 0.2 & 0.2 & - & - & 0.2 \\
\hline Butyric acid & - & - & - & 0.2 & - & 0.2 & - & 0.2 & - & 0.2 \\
\hline Propionic acid & - & - & - & - & 0.2 & 0.2 & - & - & 0.2 & 0.2 \\
\hline Total & 100 & 100 & 100 & 100 & 100 & 100 & 100 & 100 & 100 & 100 \\
\hline CP(\%) & 25.0 & 21.5 & 21.5 & 21.5 & 21.5 & 21.5 & 25.0 & 25.0 & 25.0 & 25.0 \\
\hline ME (Kcal/kg) & 2900 & 2950 & 2950 & 2950 & 2950 & 2950 & 2900 & 2900 & 2900 & 2900 \\
\hline
\end{tabular}

*Indicates over and above the hundred

Table.2 Biochemical and gut health parametars

\begin{tabular}{|l|c|c|c|c|c|}
\hline Treatments & $\begin{array}{c}\text { Total Protein } \\
(\mathbf{m g} / \mathbf{d l})\end{array}$ & $\begin{array}{c}\text { Albumin } \\
(\mathbf{m g} / \mathbf{d l})\end{array}$ & $\begin{array}{c}\text { Globulin } \\
(\mathbf{m g} / \mathbf{d l})\end{array}$ & $\begin{array}{c}\text { Cholesterol } \\
(\mathbf{m g} / \mathbf{d l})\end{array}$ & $\begin{array}{c}\text { Triglyceride } \\
(\mathbf{m g} / \mathbf{d l})\end{array}$ \\
\hline T0 & $2.91 \pm 0.007^{\mathrm{a}}$ & $1.32 \pm 0.011^{\mathrm{a}}$ & $1.59 \pm 0.013^{\mathrm{a}}$ & $232.87 \pm 4.48^{\mathrm{d}}$ & $164.26 \pm 1.08^{\mathrm{a}}$ \\
\hline T1 & $3.48 \pm 0.021^{\mathrm{b}}$ & $1.54 \pm 0.014^{\mathrm{b}}$ & $1.94 \pm 0.033^{\mathrm{bc}}$ & $234.25 \pm 1.96^{\mathrm{d}}$ & $162.45 \pm 1.82^{\mathrm{a}}$ \\
\hline T2 & $3.69 \pm 0.016^{\mathrm{c}}$ & $1.66 \pm 0.007^{\mathrm{c}}$ & $2.03 \pm 0.016^{\mathrm{cd}}$ & $195.87 \pm 0.71^{\mathrm{a}}$ & $162.67 \pm 1.94^{\mathrm{a}}$ \\
\hline T3 & $3.54 \pm 0.052^{\mathrm{b}}$ & $1.65 \pm 0.005^{\mathrm{c}}$ & $1.89 \pm 0.06^{\mathrm{b}}$ & $222 \pm 2.02^{\mathrm{c}}$ & $163.80 \pm 0.78^{\mathrm{a}}$ \\
\hline T4 & $3.74 \pm 0.008^{\mathrm{c}}$ & $1.65 \pm 0.004^{\mathrm{c}}$ & $2.09 \pm 0.029^{\mathrm{d}}$ & $213.12 \pm 2.06^{\mathrm{b}}$ & $161.29 \pm 1.30^{\mathrm{a}}$ \\
\hline Pooled Mean & $\mathbf{3 . 4 7 \pm . 0 4 9}$ & $\mathbf{1 . 5 6} \pm \mathbf{0 . 0 2 1}$ & $\mathbf{1 . 9 1} \pm .032$ & $\mathbf{2 1 9 . 6 2} \pm \mathbf{2 . 5 1}$ & $\mathbf{1 6 2 . 9 0}^{\mathrm{a}} \pm \mathbf{0 . 6 3}$ \\
\hline
\end{tabular}




\begin{tabular}{|c|c|c|c|c|c|c|}
\hline $\begin{array}{l}\text { Treatment } \\
\text { Particular }\end{array}$ & T0 & T1 & $\mathbf{T 2}$ & T3 & T4 & $\begin{array}{c}\text { Pooled } \\
\text { Mean }\end{array}$ \\
\hline Ileal pH & $6.41 \pm 0.00^{\mathrm{e}}$ & $\begin{array}{c}6.34 \pm \\
0.00^{d}\end{array}$ & $\begin{array}{r}5.96 \\
\pm 0.00^{c}\end{array}$ & $\begin{array}{c}5.63 \pm \\
0.00^{\mathrm{b}}\end{array}$ & $\begin{array}{c}5.52 \pm \\
0.00^{\mathrm{a}}\end{array}$ & $\begin{array}{c}5.97 \\
\pm 0.05\end{array}$ \\
\hline Intestinal Length & $59.43 \pm 2.44$ & $\begin{array}{c}55.30 \pm 1.0 \\
3^{\mathrm{a}}\end{array}$ & $\begin{array}{r}52.49 \\
\pm 2.13^{\mathrm{a}}\end{array}$ & $\begin{array}{c}54.32 \\
\pm 3.12^{\mathrm{a}}\end{array}$ & $\begin{array}{c}58.19 \\
1.69^{\mathrm{a}}\end{array}$ & $\begin{array}{l}55.94 \\
\pm 1.01\end{array}$ \\
\hline Int. wt & $6.00 \pm 0.30^{\mathrm{bc}}$ & $\begin{array}{c}5.98 \pm \\
0.10^{\text {bc }}\end{array}$ & $\begin{array}{r}6.14 \\
\pm 0.08^{c}\end{array}$ & $\begin{array}{c}5.66 \pm \\
0.06^{\mathrm{ab}}\end{array}$ & $\begin{array}{c}5.51 \\
0.07^{\mathrm{a}}\end{array}$ & $\begin{array}{c}5.86 \\
\mathbf{\pm 0 . 0 7}\end{array}$ \\
\hline Int. Thickness & $0.38 \pm 0.01^{\mathrm{c}}$ & $\begin{array}{c}0.41 \\
0.00^{\mathrm{d}}\end{array}$ & $\begin{array}{c}0.27 \\
\pm 0.00^{\mathrm{a}}\end{array}$ & $\begin{array}{c}0.33 \pm \\
0.00^{\mathrm{b}}\end{array}$ & $\begin{array}{c}0.27 \\
0.00^{\mathrm{a}}\end{array}$ & $\begin{array}{c}0.33 \\
\pm 0.00\end{array}$ \\
\hline E.Coli $\left(* 10^{7} \mathrm{CFU} / \mathrm{g}\right)$ & $7.24 \pm 0.00^{b}$ & $\begin{array}{l}7.15 \text { 士 } \\
0.06^{\mathrm{b}}\end{array}$ & $\begin{array}{c}6.84 \\
+0.014 \\
\mathrm{~b}\end{array}$ & $\begin{array}{c}5.79{ }^{ \pm} \\
0.38^{a}\end{array}$ & $\begin{array}{c}5.72 \\
0.35^{\mathrm{a}}\end{array}$ & $\begin{array}{r}6.55 \\
\pm 0.14\end{array}$ \\
\hline $\begin{array}{l}\text { Salmonella }\left(* 10^{7}\right. \\
\text { CFU/g) }\end{array}$ & $4.50 \pm 0.32^{b}$ & $\begin{array}{c}2.84 \\
0.02^{\mathrm{a}}\end{array}$ & $\begin{array}{c}2.74 \\
\pm 0.02^{a}\end{array}$ & $\begin{array}{c}2.86 \pm \\
0.02^{\mathrm{a}}\end{array}$ & $\begin{array}{c}2.67 \pm \\
0.01^{\mathrm{a}}\end{array}$ & $\begin{array}{c}3.12 \\
\pm 0.12\end{array}$ \\
\hline
\end{tabular}

Treatments in column bearing common superscripts doesn't differ significantly $(\mathrm{P}<0.05)$

The results of present study with respect to triglyceride was found to be similar with biochemical profile of hens given by Brzoska et al., (2013) and Yesilbag and Colpan (2006) in chicken. On the other hand, Fouladi et al., (2017) recorded significant difference in terms of triglyceride in Japanese quail.

This results obtained in present study are in agreement with Ishfaq et al., (2015) who reported significant difference in terms of intestinal $\mathrm{pH}$ in broiler chickens. However, Kral et al.. (2011) and Abdel-Fattah et al., (2008) found non-significant differences in GI-tract segments. Huff et al., (1994) who performed a study to determine the effects of propionic acid-based mold inhibitor (Mycocurb $^{\circledR}$ ), calcium propionate and propionic acid on intestinal $\mathrm{pH}$. Cobb x Cobb male broiler chicks and revealed the nonsignificant result among all treatment groups. In accordance with results obtained in present study Rehman et al., (2016) worked on the influence of dietary acetic acid found higher intestinal weight. results corroborates with Kum et al., (2010) and Kaya et al., (2004) who found significant difference among treatment groups when broiler birds were feddiet supplemented with organic acids supplemented diet. Rodjan et al., (2017) who evaluated the effect of organic acids or probiotics alone or in combination on gut health of broiler chickens and reported significant result. However, Gul et al., (2014) and Paul et al., (2007) found non-significant differences for $E$. coli count among treatments and control. The results of the present study are in accordance with Kazempour and Jahanian (2017) and Abdel et al., (2012) who found significant results.

\section{Acknowledgments}

Special thanks to Dr. S.M. Wankhede (Assistent-Professor \& Head, Dept. of ANN, COVAS, Parbhani), Dr. S. Sajid Ali (Assistent-Professor \& Head, Dept. of AGB, PGIVAS,Akola.) for their valuable guidance..

\section{References}

Abdel-Fattah, S.A, M.H. EI-Sanhoury, N.M. EI-Mednay and F. Abdul-Azeem (2008) Thyroid activity of broiler chicks fed supplemental organic acids. Int. J. Poult. Sci. 7:215-222. 
Abdel-Mageed, M.A.A. (2012) Effect of using organic acids on performance of Japanese quail fed optimal and suboptimal energy and protein levels 2 . Butyric acid. Egypt. Poult. Sci. 32(3)625-644.

Attia, Y.A., Böhmer, B.M. and Roth-Maier, D.A. (2006) Responses of broiler chicks raised under constant relatively high ambient temperature to enzymes, amino acid Supplementations, or diet density. Arch. Geflugelkd, 70:80-91.

Attia, Y.A., Ellakany, H.F., Abd El-Hamid, A.E., Bovera, F., Ghazaly, S.A. (2012) Growing and laying performance of Japanese quail fed diet supplemented with different concentrations of acetic acid. Ital. J. Anim. Sci., 12: e37.

Aziz-mousavi, S.M.A., A.R. Seidavi and Dadashbeiki, M. (2012) Effect of different levels of synbiotics on carcass characteristics of broiler. Res. Opin. Anim. Vet. Sci., 2: 161-165.

BrzoskaFranciszek, BogdanŚliwiński and Olga Michalik-Rutkowska (2013) Effect of dietary acidifier on growth, mortality, post-slaughter parameters and meat composition of broiler chickens. Ann. Anim. Sci. 13(1):8596.

Elnesr, S. S., A. Ropy and A. H. Abdel-Razik (2018) Effect of dietary sodium butyrate supplementation on growth, blood biochemistry, haematology and histomorphometry of intestine and immune organs of Japanese quail The Anim. Consortium, 1.

FAO, 2019.Gateway to poultry production and products. Poultry Species.

Fouladi, P., Y. Ebrahimnezhad, H. Aghdam Shahryar, N. Maheri, A. Ahmadzadeh. (2018). Effects of organic acids supplement on performance, egg traits, blood serum biochemical parameters and gut microflora in female Japanese quail (Coturnix coturnix Japonica). Brazilian J. Poult. Sci. 20(1):133-144.

Gama, N.M.S.Q., M.B.C. Olivera, E. Santinand J. Berchieri (2000) Supplementation with organic acids in diets of lying hens. Ciencia Rural; 30: 499-502.

Huff, W. E., J. M. Balog, G. R. Bayyari and N.C. Rath (1994) The effect of mycocurb, propionic acid, and calcium propionate on the intestinal strength of broiler chickens. Poult. Sci.73(8): 352-1356.

Ishfaq A., S. A. Rather, A. H. Mir and M. Gupta (2015) Effect of Acipure (feed acidifier) on the growth performance, mortality and gut $\mathrm{pH}$ of broiler chickens.IJLR.5 (10), 40-46.

Hatice Kaya, Adem Kaya, Mehmet Gul, ŞabanÇelebi, Sema Timurkaanand Betuil Apaydin (2014). Effects of supplementation of different levels of organic acids mixture to the diet on performance, egg quality parameters, serum traits and histological criteria of laying hens. Europian Poult. Sci, pp 78.

Kral, M., M. Angelovičová, L. Mrazova, J. Tkacova and M. Kliment (2011) Probiotic and acetic acid of broiler chickens performance. Scientific Papers Animal Science and Biotechnologies, 44, 149-152.

Kum, S., U. Eren, A.G. Onol and M. Sandikci (2010) Effects of dietary organic acid supplementation on the intestinal mucosa in broilers.

Langhout, P and T. Sus (2005). Volatile fatty acids improve performance and quality. Int. Poult. Prod., 13 (3):17.

Naveenkumar, S., N. Karthikeyan, R. Narendra Babu, P. Veeramani, S. Sivarama Krishnani and G Srinivasan (2018) Effect of calcium propionate and coated sodium butyrate as an alternative to antibiotic growth 
promoters on the serum profile of commercial broiler chicken. Int. J. Chemical Studies.

Patten, J. D. and P. W. Waldroup (1988) Use of organic acids in broiler diets. Poultry Science, 67, 1178-1182.

Poultry sector in India (2017) Poultry sector, opportunities and challenges in India. Netherlands business support office Hyderabad, India R.V.O.H.

Rahman, M. S., M. A. R. Howlider, M. Mahiuddin and M. M. Rahman (2008) Effect of supplementation of organic acids on laying performance, body fatness and egg quality of hens. Bang. J. Anim. Sci., 37(2): 74-81..

Seifi, S., R. Sayrafi, R. Khoshbakht and A. Gilani (2015) Effects of dietary acetic acid on intestinal microbiota, serum components, internal organs and performance of broilers. Global J. Anim. Sci. Res. 3(2), 536-543.

RaminShamlo, Javad Nasr and FarshidKheiri (2014) Effects of various levels of pennyroyal (Mentha pulegium L.) on carcass characteristics and serum cholesterol in broiler. Research Opinion Animal Veterinary Science, 4, 453-457.

Skinner, J.T., A.L. Izat and P.W., Waldroup (1991). Fumaric acid enhances performance of broiler chickens. Poult Sci; 70:1444-1447.

Snedecor G.W. and Corchan W.G. (1994) Statistical Method, 9th Edition, Oxford and IBH publishing Co. Pvt. Ltd, New Delhi.

SPSS, (2009). Statistical Package for the Social Sciences Version.

Vogt, H., S. Matthes and S. Harnisch (1981). The influence of organic acids on the performance of Broilers. 2. Communication. Archive for Poultry Customer 46:223-227 hens. Archives for poultry studies 45:221-232.

Yesilbag, D. and I. Çolpan (2006) Effects of Organic Acid Supplemented Diets on Growth Performance, Egg Production and Quality and on Serum Parameters in Laying Hens, Revue Méd. Vét. 157(5): 280-284.

\section{How to cite this article:}

Bansod, A. P., S. M. Wankhede, Sajid Ali, Prajakta S. Kuralkar, G. M. Jadhao and Jadhao, A. D. 2020. Effect of Supplementation of Organic Acids on Biochemical Status and Gut Health of Japanese Quail (Coturnixcoturnix japonica). Int.J.Curr.Microbiol.App.Sci. 9(02): 837-843. doi: https://doi.org/10.20546/ijcmas.2020.902.101 